\title{
¿Middle East Climate Response to the Saharan Vegetation Collapse during the Mid-Holocene
}

\author{
WeiYi Sun, ${ }^{\mathrm{a}}$ Bin WAng, ${ }^{\mathrm{b}}$ Qiong Zhang, ${ }^{\mathrm{c}}$ Deliang Chen, ${ }^{\mathrm{d}}$ GuONIAN Lu, ${ }^{\mathrm{a}}$ ANd JiAn LiU ${ }^{\mathrm{a}, \mathrm{e}, \mathrm{f}}$ \\ ${ }^{a}$ Key Laboratory for Virtual Geographic Environment, Ministry of Education, State Key Laboratory Cultivation Base of \\ Geographical Environment Evolution of Jiangsu Province, Jiangsu Center for Collaborative Innovation in Geographical \\ Information Resource Development and Application, School of Geography Science, Nanjing Normal University, Nanjing, China \\ ${ }^{\mathrm{b}}$ Department of Atmospheric Sciences and International Pacific Research Center, University of Hawai $i$ at Mānoa, Honolulu, Hawaii \\ ${ }^{\mathrm{c}}$ Department of Physical Geography and Bolin Centre for Climate Research, Stockholm University, Stockholm, Sweden \\ ${ }^{\mathrm{d}}$ Regional Climate Group, Department of Earth Sciences, University of Gothenburg, Gothenburg, Sweden \\ ${ }^{\mathrm{e}}$ Jiangsu Provincial Key Laboratory for Numerical Simulation of Large Scale Complex Systems, School of Mathematical Science, \\ Nanjing Normal University, Nanjing, China \\ ${ }^{\mathrm{f}}$ Open Studio for the Simulation of Ocean-Climate-Isotope, Qingdao National Laboratory for Marine Science and Technology,
} Qingdao, China

(Manuscript received 4 May 2020, in final form 1 October 2020)

\begin{abstract}
Understanding climate change in the Middle East (ME) is crucial because people's living environment depends on rain-fed crop systems. It remains unclear whether the ME climate would be affected by the Saharan vegetation collapse at the end of the mid-Holocene $(\mathrm{MH})$. Proxy data suggest a transition from humid to more arid ME conditions during the period of 6.5-5 kyr BP. Using a set of idealized sensitivity experiments with an Earth system model (EC-Earth), we infer that the shift of Saharan vegetation plays a role in this wet-to-dry transition over the ME. The experimental results show that the Saharan greening can significantly increase the late winter and early spring precipitation over the ME. The reason is that the vegetation decreases the surface albedo, which induces a warming in North Africa and generation of an anomalous low-level cyclonic flow, which transports moisture from tropical North Africa and the Red Sea to the ME. The moisture also flows from the Mediterranean Sea region to the ME through the enhanced mid- to upper-level westerlies. The enhanced moisture carried by westerly and southwesterly flows is lifted upon reaching Mesopotamia and the Zagros Mountains, substantially increasing the precipitation there. When the Sahara greening is removed, a drier condition happens in the ME. The crop model simulation further shows a substantial decrease in wheat yield in Mesopotamia with the reduction of Saharan vegetation, which is consistent with paleoclimatic reconstructions. These results imply that future changes in Saharan land cover may have climatic and agricultural impacts in the Middle East.
\end{abstract}

KEYWORDS: Atmosphere; Mediterranean Sea; Atmosphere-land interaction; Paleoclimate; Coupled models; Agriculture

\section{Introduction}

The Middle East (ME) is a highly water-stressed region, with different climates including Mediterranean, arid, and semiarid regions. Unlike as observed in summer monsoonal or typically Mediterranean climate regimes, present-day observations show that the ME precipitation features a winter/earlyspring rainy season (i.e., Evans 2009). A drying trend is projected in the warming climate (Mariotti et al. 2015; Barcikowska et al. 2018), which may affect agriculture, water management, and political conflict.

During the Holocene, the evolution of cereal-agriculturebased societies over the ME may have been associated with climate change (Staubwasser and Weiss 2006). The reconstructions show that agriculture was evolved before 6000 years before the present (BP), thanks to the relatively wet climate in the ME region (Araus et al. 2007; Roberts et al. 2011a,b; Riehl et al. 2014). The Ubaid period villages then developed in

¿ Denotes content that is immediately available upon publication as open access.

Corresponding author: Jian Liu, jliu@njnu.edu.cn
Mesopotamia and the Uruk period cities and Sumerian civilization were established (Staubwasser and Weiss 2006). After that, a well-known $5.2 \mathrm{kyr}$ (i.e., $5200 \mathrm{yr}$ ) BP drought event occurred over the ME (i.e., Staubwasser and Weiss 2006; Zanchetta et al. 2014), which decreased the Tigris and Euphrates streamflow (Nutzel 2004) and affected the inland cereal agriculture regions (Weiss 1986; Riehl et al. 2014). At the same time, the abrupt collapse of the Late Uruk society and settlement urbanization occurred across Mesopotamia (Staubwasser and Weiss 2006; Nissen 1988), which can be tied to the climate fluctuations and associated crop production (Riehl et al. 2014). Thus, it is extremely important to understand the hydrological shifts over the ME during the mid-Holocene ( $\mathrm{MH})$ and their impact on agriculture.

Some reconstructions suggest a drier condition over the ME during the end of mid-Holocene (Roberts et al. 2011b; Clarke et al. 2016; Sharifi et al. 2015), such as a severe 600-yr drought at 5.5 kyr BP in the Zagros Mountains (Stevens et al. 2006) and an increase in Arabian aridity after $5.5 \mathrm{kyr}$ BP (Sirocko et al. 1993). Magny and Hass (2004) suggested that the direct forcing of climatic change could be associated with the orbital parameters, oceanic circulation, and solar activity minima, but the specific physical processes were still unclear. Meanwhile, the orbital forcing is also considered to be the cause of the 
relatively wet ME and eastern Mediterranean conditions before $6 \mathrm{kyr} \mathrm{BP}$, but the possible processes are being intensely debated: 1) the orbital forcing causes a strong summer AfricanAsian monsoon, which leads to the enhanced monsoon precipitation in the ME region (Wanner et al. 2008; Waldmann et al. 2010);2) a positive North Atlantic Oscillation (NAO) and strengthened westerly circulation in winter contribute to the increased precipitation over the eastern Mediterranean region (Davis and Stevenson 2007; Mauri et al. 2014); and/or 3) some other regional processes contribute to the wet condition (Roberts et al. 2011a).

At the same time, the insolation change substantially strengthened the African monsoon during the early to middle Holocene (Kutzbach and Otto-Bliesner 1982; Claussen and Gayler 1997). This is because the increased boreal summer insolation causes a warmer land relative to the surrounding ocean (Kutzbach 1981), which strengthens the North African monsoon and expands the vegetation coverage (Hoelzmann et al. 1998; Tuenter et al. 2007; Rachmayani et al. 2016; Skinner and Poulsen 2016). The expanded vegetation fraction over the Sahara can further enhance the West African monsoon precipitation (Kutzbach et al. 1996). This positive feedback made the Sahara Desert covered by shrubland and grassland (Watrin et al. 2009; Hély et al. 2014), creating the "green Sahara" (deMenocal et al. 2000; Kröpelin et al. 2008). Nevertheless, using orbitally forced simulations, researchers have failed to reproduce the northward expansion of the African monsoon in the $\mathrm{MH}$, primarily due to neglecting the impacts of Saharan greening (Braconnot et al. 2012; Harrison et al. 2014; Tierney et al. 2017). Using the climate simulations based on the projection of $\mathrm{MH}$ vegetation over the Sahara, Saudi Arabia (Hoelzmann et al. 1998), and Eurasia, Swann et al. (2014) found a greater increase in precipitation over the Sahara and Saudi Arabia, compared with the orbital forcing alone. Around the end of MH, the desertification of green Sahara occurred at about 5.5 kyr BP (McGee et al. 2013; Armitage et al. 2015; Shanahan et al. 2015; Collins et al. 2017), which may be due to the decreased summer insolation in the Northern Hemisphere.

Some studies have suggested that the shift of green Sahara not only locally influenced the North African monsoon but also affected the large-scale atmospheric circulation and remotely influenced the Arctic climate (Davies et al. 2015; Muschitiello et al. 2015) and tropical climate (Pausata et al. 2017a,b; Sun et al. 2019) during the MH. Proxy data from northwest Iran suggested a wetter period during the early Holocene (9-6 kyr $\mathrm{BP}$ ), which was followed by a drier and dustier condition (Sharifi et al. 2015). Using the model simulations based on the vegetation cover change (Hoelzmann et al. 1998), Sharifi et al. (2018) further found that the greening of North Africa contributes to a decrease in dust loading and an increase (decrease) in boreal summer (winter) precipitation minus evaporation in northwest Iran. However, their study only focused on one site, and the reason for the simulated ME precipitation change remained unclear.

Can the shift of Saharan greening influence the ME climate during the MH? If so, what is the mechanism by which ME climate changes, and what is the impact of that change on agricultural yields? To address these questions, we will test the
TABLE 1. Description of the model experiments.

\begin{tabular}{lccc}
\hline \hline \multicolumn{1}{c}{ Expt } & Orbital forcing & \multicolumn{1}{c}{ GHGs } & Saharan vegetation \\
\hline PI & $1850 \mathrm{AD}$ & $1850 \mathrm{AD}$ & Desert \\
PI $_{\text {GREEN }}$ & $1850 \mathrm{AD}$ & $1850 \mathrm{AD}$ & Shrub \\
MH $_{\text {DESERT }}$ & $6000 \mathrm{yr} \mathrm{BP}$ & $6000 \mathrm{yr} \mathrm{BP}$ & Desert \\
MH $_{\text {GREEN }}$ & $6000 \mathrm{yr} \mathrm{BP}$ & $6000 \mathrm{yr} \mathrm{BP}$ & Shrub \\
\hline
\end{tabular}

sensitivity of the rapid climate change over the ME to the Saharan land cover change during the $\mathrm{MH}$ based on the reconstructions and the simulations from the EC-Earth climate model. From the results of idealized simulations, we will show the changes in precipitation, temperature, and atmospheric circulation over the ME under the difference between a green Sahara and a desert Sahara condition, and the underlying mechanism will be elaborated. The differences in daily solar radiation and maximum/minimum temperature between the $\mathrm{MH}_{\text {DESERT }}$ and $\mathrm{MH}_{\mathrm{GREEN}}$ experiments are small over Mesopotamia, but the change in daily precipitation is significant. Since the EC-Earth climate model does not simulate crop yields, a crop model will be useful to investigate if the change in wheat yield over Mesopotamia is affected by the precipitation change during the mid-Holocene (Holzworth et al. 2014; Riehl et al. 2014).

\section{Methods}

\section{a. Climate model and experiments}

In this study, we use climate model EC-Earth, version 3.1 (Hazeleger et al. 2010). The atmospheric model is based on the Integrated Forecast System (IFS cycle 36r4), including a land model H-TESSEL. The resolution of IFS is T159 (roughly $125 \mathrm{~km}$ ) with 62 vertical levels. The oceanic model is version 3 of the Nucleus for European Modeling of the Ocean (NEMO; Madec 2008), with a horizontal resolution of $\sim 1^{\circ}$ and 46 vertical levels. The model is coupled with the Louvain-la-Neuve Sea Ice Model, version 3 (LIM3; Vancoppenolle et al. 2009), and the coupling device is the OASIS3 coupler (Valcke 2006).

We performed a CMIP5 historical run for a 30-yr period from 1979 to 2008 for model evaluation. The preindustrial (PI; $1850 \mathrm{AD})$ experiment is carried out with initial conditions from a 700-yr spinup run (Table 1). The initial values are similar to the CMIP5 protocol (Taylor et al. 2012) and the Sahara region $\left(11^{\circ}-33^{\circ} \mathrm{N}, 15^{\circ} \mathrm{W}-35^{\circ} \mathrm{E}\right)$ is covered mainly by the desert. The sensitivity experiments are then run for 300-400 years. The quasi equilibrium is reached after 100-200 years, which depends on the experiment. This research focuses on the last 100 years of each experiment. The sensitivity experiments are performed by Pausata et al. (2016). In the idealized experiment named $\mathrm{PI}_{\text {GREEN }}$, we replace the desert with shrub vegetation over the Sahara region $\left(11^{\circ}-33^{\circ} \mathrm{N}, 15^{\circ} \mathrm{W}-35^{\circ} \mathrm{E}\right)$ under the preindustrial condition. The surface albedo is 0.30 for desert (in the PI) and 0.15 for shrub (in the $\mathrm{PI}_{\mathrm{GREEN}}$ ), respectively. Correspondingly, the leaf area index is 0.2 for desert and 2.6 for shrub, respectively. The standard $\mathrm{MH}$ simulation is performed following the protocol of the Paleoclimate Modeling 
(a) $\operatorname{Pr} \& 850 \mathrm{hPa} U V$

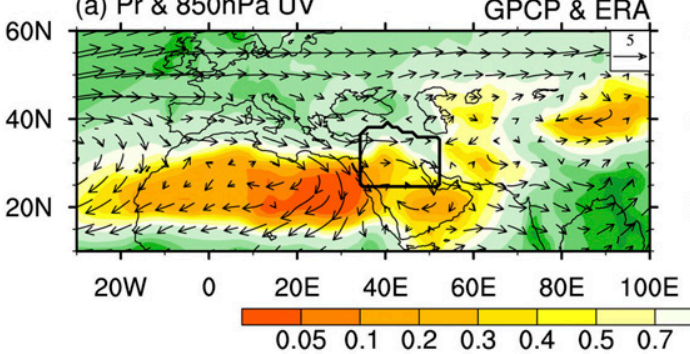

(b) Pr \& 850hPa UV

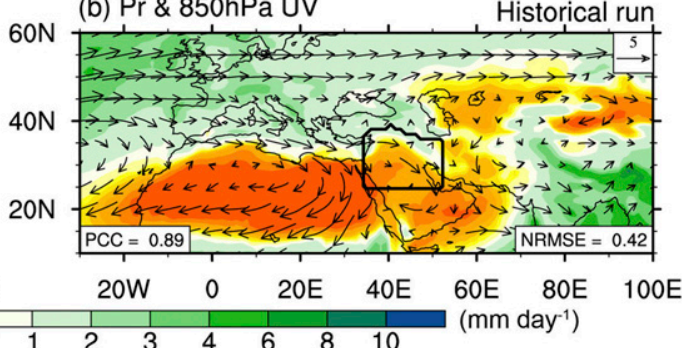

(c) NDJFMA / Year (\%)

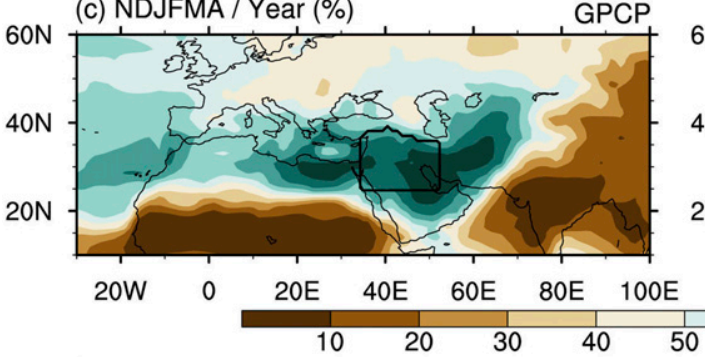

(d) NDJFMA / Year (\%)

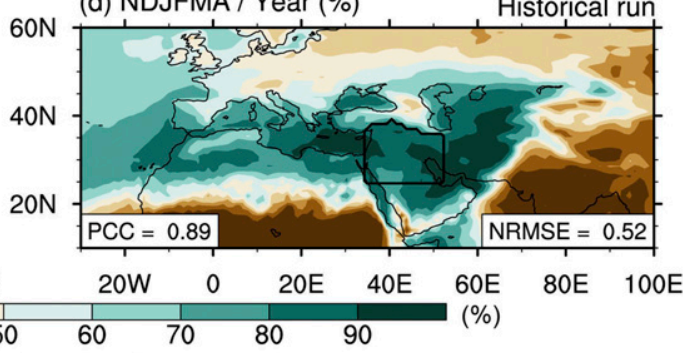

(e) Rainy peak month

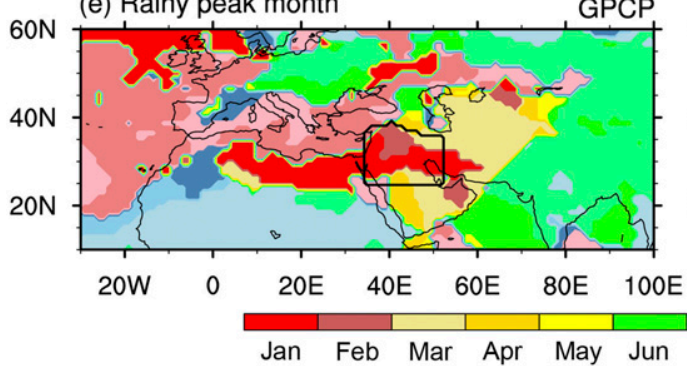

(f) Rainy peak month

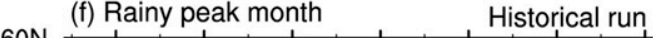

FIG. 1. (a),(b) Annual mean precipitation $\left(\mathrm{mm} \mathrm{day}^{-1}\right)$; (c),(d) cold season divided by annual precipitation (\%); and (e),(f) month with the largest precipitation in (left) GPCP and (right) the Historical run during 1979-2008. Vectors in (a) and (b) denote the winds at $850 \mathrm{hPa}$ in ERA during 1979-2008. The cold season refers tos NovemberApril in the Northern Hemisphere. Black boxes represent the Middle East region. The numbers in the lower-left and lower-right corners in the right panels indicate the pattern correlation coefficient (PCC) and normalized rootmean-square-error (NRMSE) between the simulated and observed precipitation.

Intercomparison Project 3 (PMIP3), where orbital forcing is set at about $6 \mathrm{kyr} \mathrm{BP}$, but the Sahara is covered by the desert $\left(\mathrm{MH}_{\text {DESERT }}\right)$. For the greenhouse gases, methane is set at 760 ppmv in PI and 650 ppmv in the $\mathrm{MH}_{\text {DESERT }}$ experiment, and there is no change in $\mathrm{CO}_{2}$ and other greenhouse gases. The third sensitivity experiment $\left(\mathrm{MH}_{\mathrm{GREEN}}\right)$ is imposed by the prescribed shrub vegetation type over the Sahara domain under the $\mathrm{MH}$ conditions.

\section{b. Observational and proxy data and definition of study area}

The dataset of the Global Precipitation Climatology Project (GPCP), version 2.3 (Adler et al. 2003), which provides global (land and ocean) coverage for the period of 1979-2008, was used to evaluate the model performance of the climatological pattern. The atmospheric circulation fields are derived from the reanalysis dataset, which is made by merging the $40-\mathrm{yr}$ ECMWF Re-Analysis (ERA-40) during the period 1958-2001 (Uppala et al. 2005) and the ERA5 reanalysis during the period 1979-2019 (Hersbach et al. 2018). The monthly 2-m air temperature and daily maximum/minimum temperature used in this study are derived from the National Centers for Environmental Prediction reanalysis 2 (NCEP2) (Kanamitsu et al. 2002)

The black-outlined box in Fig. 1 represents the region of the Middle East $\left(34^{\circ}-52^{\circ} \mathrm{E}, 25^{\circ}-38^{\circ} \mathrm{N}\right)$, which includes Syria, Mesopotamia, and the central-northern Arabian Peninsula. Since the ME precipitation mainly occurs in winter and spring, the northern boundary of the ME is defined according to the precipitation, where the cold season precipitation divided by annual precipitation is $70 \%$ in the historical run (Fig. 1d). Our model operates well in simulating the annual mean precipitation, winds at $850 \mathrm{hPa}$, boreal cold season (November-April) divided by annual precipitation, and rainy peak month over the Mediterranean-West Asian region (Fig. 1), compared with the observation and reanalysis data. From the Mediterranean to the West Asian region, the rainy peak season gradually changes from winter to spring (Fig. 1e). The precipitation peaks in January-March over the ME, especially over Mesopotamia. 
TABLE 2. Proxy records used in this study to infer the changes in precipitation. Data in the ME are displayed in boldface type.

\begin{tabular}{|c|c|c|c|c|c|c|}
\hline & Region & Proxy type & Lat & Lon & $\begin{array}{l}\text { Transition } \\
\text { in the MH }\end{array}$ & Reference \\
\hline 1-2 & Soreq Cave & $\delta^{18} \mathrm{O}$ and $\delta^{13} \mathrm{C}$ from speleothems & $31^{\circ} 27^{\prime} \mathbf{N}$ & $3^{\circ} \mathbf{E}$ & $\begin{array}{l}\text { Wet to dry } \\
\text { No change }\end{array}$ & $\begin{array}{l}\text { Bar-Matthews et al. (2000); } \\
\text { Zanchetta et al. (2014) }\end{array}$ \\
\hline 3 & Red Sea & Sediment from core GeoB5804-4 & $29^{\circ} 42^{\prime} \mathbf{N}$ & $34^{\circ} 57^{\prime} \mathrm{E}$ & Wet to dry & Arz et al. (2003) \\
\hline 4 & Red Sea & Sediment from core GeoB5844-2 & $27^{\circ} 06^{\prime} \mathbf{N}$ & $34^{\circ} 24^{\prime} \mathrm{E}$ & Wet to dry & Arz et al. (2003) \\
\hline 5 & Hoti Cave & $\delta^{18} \mathrm{O}$ & $23^{\circ} 05^{\prime} \mathrm{N}$ & $57^{\circ} 21^{\prime} \mathrm{E}$ & Wet to dry & Fleitmann and Matter (2009) \\
\hline 6 & Qunf Cave & $\delta^{18} \mathrm{O}$ & $17^{\circ} 10^{\prime} \mathrm{N}$ & $54^{\circ} 18^{\prime} \mathrm{E}$ & Wet to dry & Fleitmann and Matter (2009) \\
\hline 7 & Jeita Cave & $\delta^{18} \mathrm{O}$ and $\delta^{13} \mathrm{C}$ from speleothems & $32^{\circ} 56^{\prime} \mathrm{N}$ & $\mathbf{3 5}^{\circ} 38^{\prime} \mathbf{E}$ & Wet to dry & Verheyden et al. (2008) \\
\hline 8 & Levantine Sea & Sediment cores from SL112 & $32^{\circ} 44^{\prime} \mathrm{N}$ & $\mathbf{3 4}^{\circ} 39^{\prime} \mathbf{E}$ & Wet to dry & Hamann et al. (2008) \\
\hline 9 & $\begin{array}{l}\text { Broken-Leg Cave } \\
\text { and Star Cave }\end{array}$ & $\delta^{18} \mathrm{O}$ and $\delta^{13} \mathrm{C}$ from speleothems & $29^{\circ} 55^{\prime} \mathbf{N}$ & $\mathbf{4 1}^{\circ} \mathbf{3 0} \mathbf{E}^{\prime} \mathrm{E}$ & No change & Fleitmann et al. (2004) \\
\hline 10 & Surprise Cave & $\delta^{18} O$ and $\delta^{13} \mathrm{C}$ from speleothems & $26^{\circ} 30^{\prime} \mathbf{N}$ & $48^{\circ} 20^{\prime} \mathbf{E}$ & No change & Fleitmann et al. (2004) \\
\hline 11 & Nefud & $\begin{array}{l}\text { Lithological and geomorphological } \\
\text { evidence }\end{array}$ & $25^{\circ} 36^{\prime} \mathbf{N}$ & $42^{\circ} 39^{\prime} \mathbf{E}$ & Wet to dry & Whitney et al. (1983) \\
\hline 12 & Neor Lake & Compound-specific $\delta D(\%)$ & $37^{\circ} 57^{\prime} \mathbf{N}$ & $\mathbf{4 8}^{\circ} 33^{\prime} \mathbf{E}$ & Wet to dry & Sharifi et al. (2015) \\
\hline 13 & Mirabad & $\delta^{18} \mathrm{O}$ & $3^{\circ} 05^{\prime} \mathbf{N}$ & $47^{\circ} 43^{\prime} \mathrm{E}$ & Wet to dry & Stevens et al. (2006) \\
\hline 14 & Zeribar & $\delta^{18} O$ & $\mathbf{3 5}^{\circ} \mathbf{3 2} \mathbf{\prime}^{\prime} \mathbf{N}$ & $46^{\circ} 07^{\prime} \mathrm{E}$ & Wet to dry & Stevens et al. (2006) \\
\hline 15 & Gölhisar Gölü & Lake sediments & $37^{\circ} 08^{\prime} \mathrm{N}$ & $29^{\circ} 36^{\prime} \mathrm{E}$ & Wet to dry & Eastwood et al. (2007) \\
\hline 16 & Eski Acigöl & Lake sediments & $38^{\circ} 33^{\prime} \mathrm{N}$ & $34^{\circ} 32^{\prime} \mathrm{E}$ & Wet to dry & Roberts et al. (2001) \\
\hline 17-18 & Dead Sea & Sedimentary & $31^{\circ} 30^{\prime} \mathbf{N}$ & $\mathbf{3 5}^{\circ} \mathbf{3 0} \mathbf{0}^{\prime} \mathbf{E}$ & $\begin{array}{l}\text { Dry to wet; } \\
\text { Dry to wet }\end{array}$ & $\begin{array}{l}\text { Migowski et al. (2006); } \\
\text { Litt et al. (2012) }\end{array}$ \\
\hline 19 & Rub'at Khali & Lake sediments & $22^{\circ} 30^{\prime} \mathrm{N}$ & $49^{\circ} 40^{\prime} \mathrm{E}$ & Wet to dry & McClure (1976) \\
\hline 20 & Lake Van & $\begin{array}{l}\delta^{18} \mathrm{O} \text {, pollen and sediment } \\
\text { deposition rate }\end{array}$ & $38^{\circ} 24^{\prime} \mathrm{N}$ & $43^{\circ} 12^{\prime} \mathrm{E}$ & No change & $\begin{array}{l}\text { Wick et al. (2003); } \\
\text { Roberts et al. (2011b) }\end{array}$ \\
\hline 21 & Caspian Sea & Coastal terraces & $42^{\circ} \mathrm{N}$ & $51^{\circ} \mathrm{E}$ & Wet to dry & Overeem et al. (2003) \\
\hline
\end{tabular}

Since most reconstructions were investigated at individual sites and there is still a lack of overview of hydrological reconstructions over the ME, we collected proxy data site by site (Table 2). The choice of proxy data needs to meet several criteria. First, these data are compiled from the published literature. Second, the proxy data should reflect variation in wet/ dry changes or have a relation with precipitation. The records that only reflect temperature were not included. Third, the time series of proxies are continuous and include the 7.0 to $3.0 \mathrm{kyr}$ BP. Since the simulated results are used to be compared with proxy data before and after the desertification of Saharan vegetation (about $5.5 \mathrm{kyr} \mathrm{BP}$ ), the two periods are defined as the 1000 -yr intervals centered on $6.5 \mathrm{kyr}$ for the green Sahara period and 5.0 kyr BP for the desert Sahara period. The orbital forcing can be different at 6.5 and $5.0 \mathrm{kyr} \mathrm{BP}$, but the impact of orbital forcing during 6.5-5.0 kyr BP on ME precipitation can be neglected in the orbital-only simulation of Trace21 (figure not shown) (Liu et al. 2014). Following Muschitiello et al. (2015), the 1000-yr time window can be a suitable interval to estimate the climate change over the ME between the two periods, and it also largely reduces the high-frequency climate variability. Thus, the anomalies from the reconstructions are calculated by subtracting the $1000-\mathrm{yr}$ mean during $5 \pm 0.5 \mathrm{kyr}$ $\mathrm{BP}$ from the mean during $6.5 \pm 0.5 \mathrm{kyr} \mathrm{BP}\left(\Delta P_{6.5}-5 \mathrm{kyr}\right)$.

\section{c. The crop model}

Previous studies found that the ME crop production increased in the early-middle Holocene whereas it decreased around $5.2 \mathrm{kyr}$, which can be associated with the climate fluctuations during the MH (Riehl et al. 2014). However, to our knowledge, no study has simulated the climatic impact on the crop yields during the $\mathrm{MH}$. To check whether the shift of Saharan greening can influence the change in wheat production in the ME, a crop model is needed in this study.

The Agricultural Production Systems Simulator, version 7.7 (APSIM), is used as the crop model in this study (Holzworth et al. 2014). The input climate data of ASPIM include daily precipitation, evaporation, downwelling shortwave radiation, maximum temperature, and minimum temperature. There are two sets of idealized crop experiments and each of them is run for 20 years, based on the outputs over the last 20 years in the $\mathrm{MH}_{\text {DESERT }}$ and $\mathrm{MH}_{\mathrm{GREEN}}$ experiments. Daily precipitation, evaporation, and downwelling shortwave solar radiation are derived from the last 20 years in the $\mathrm{MH}_{\text {DESERT }}$ and $\mathrm{MH}_{\text {GREEN }}$ experiments. Since the daily maximum/minimum temperature is not output by default in the $\mathrm{MH}_{\mathrm{DESERT}}$ and $\mathrm{MH}_{\mathrm{GREEN}}$ experiments, we used the daily maximum/minimum temperature from NCEP2 during 1979-98, which was subtracted the monthly temperature in NCEP2 and added the climatological mean monthly temperature in the $\mathrm{MH}_{\mathrm{DESERT}}$ and $\mathrm{MH}_{\mathrm{GREEN}}$ experiments, respectively. Then the warming trend of daily maximum/minimum temperature is eliminated, and the climatology is equal to that in the $\mathrm{MH}$ experiments.

The area of simulation is located in Mesopotamia (north of $29^{\circ} \mathrm{N}$ in the red-outlined box of Fig. 2), where the soil types are brown clay, silty loam, and cracking clay (Buringh 1960; Moeller et al. 2014). In the PI experiment, the annual precipitation is about $216 \mathrm{~mm}$ in Mesopotamia, while the observation 
(a) Annual mean precipitation

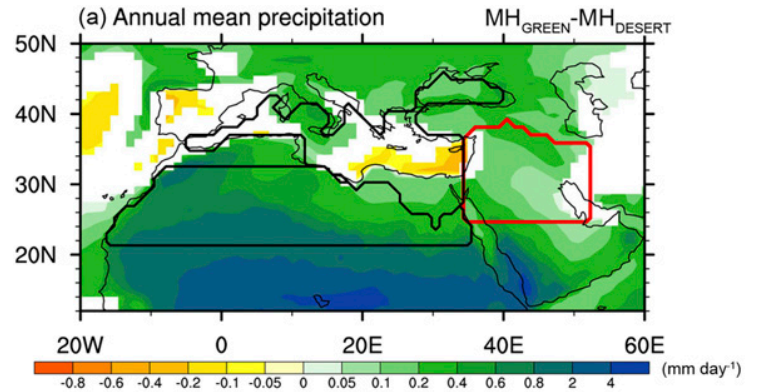

(b) Proxy change

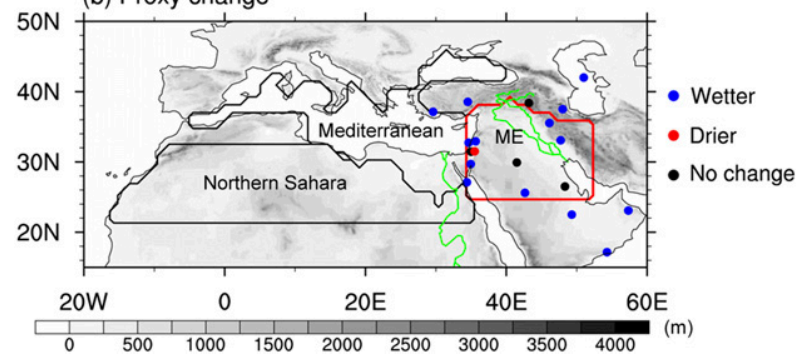

FIG. 2. Difference of the annual mean precipitation between before and during the desertification of the Saharan vegetation: (a) simulated annual mean precipitation anomalies $\left(\mathrm{mm} \mathrm{day}^{-1}\right)$ under the effect of Saharan vegetation $\left(\mathrm{MH}_{\mathrm{GREEN}}-\mathrm{MH}_{\mathrm{DESERT}}\right)$ and (b) wet/dry changes inferred from the paleoclimate archives $\left(\Delta P_{6.5-5 \mathrm{kyr}}\right)$ listed in Table 2. Shadings represent the altitude $(\mathrm{m})$. Green lines represent the major rivers. Black boxes represent the Mediterranean and northern Sahara regions, and the red box represents the Middle East region. In (a), only the significant anomalies with confidence level exceeding the $95 \%$ (via a twotailed Student's $t$ test) are shaded.

shows about 150-400 mm (i.e., Buringh 1960). The growing season is from November to May The area-average annual temperature is $16.2^{\circ}$ and $17.0^{\circ} \mathrm{C}$ in the $\mathrm{MH}_{\text {DESERT }}$ and $\mathrm{MH}_{\text {GREEN }}$ experiments, respectively. The larger temperature in the $\mathrm{MH}_{\mathrm{GREEN}}$ experiment can be associated with the enhanced northward heat transport (Muschitiello et al. 2015). Following Moeller et al. (2009, 2014), the sowing window for wheat is 1-20 December and the sowing of wheat is simulated when the amount of rainfall over 5 days is $25 \mathrm{~mm}$. If a sowing opportunity does not occur until 20 December, wheat will be sown on 21 December. The sowing depth is $0.05 \mathrm{~m}$, and the sowing density is 100 plants per square meter. The amount of plant available soil water is $50 \mathrm{~mm}$ ( $15 \%$ of maximum available water), and soil mineral nitrogen is initialized to $50 \mathrm{~kg} \mathrm{ha}^{-1}$ in $0-1.5 \mathrm{~m}$ soil depth.

\section{Results}

\section{a. Sahara greening increases rainfall over the $M E$}

The simulated results in the $\mathrm{MH}_{\mathrm{GREEN}}$ minus $\mathrm{MH}_{\mathrm{DESERT}}$ experiments represent the climate change between the Saharan green and Saharan desert periods under the $\mathrm{MH}$ condition. When the Sahara is covered by vegetation (Fig. 2a), the center of increased precipitation anomalies occurs at the TigrisEuphrates delta and Zagros Mountains where precipitation increases as much as $\sim 0.3 \mathrm{~mm}$ day $^{-1}$, compared to the precipitation in the $\mathrm{MH}_{\text {DESERT }}$ experiment (about $0.9 \mathrm{~mm} \mathrm{day}^{-1}$ ). It should be noted that the overall precipitation rate is very small, which can be subject to some relatively large uncertainty. The annual mean precipitation over the ME is substantially increased by about $34.3 \%$ when compared with the results in the deserted Saharan experiment, which is a large simulated percentage change because of the small denominator of that calculation. The simulated increased precipitation is also found over the region of North Africa, the Caspian Sea, the southeastern Arabian Peninsula, and Europe.

Nine of 14 proxy-based precipitation records show an increase in $\Delta P_{6.5-5 \mathrm{kyr}}$ over the ME (Table 2). In the northeastern $\mathrm{ME}$ (Fig. 2b), the $\delta^{18} \mathrm{O}$ records from the Lake Zeribar and Lake Mirabad reflect a wet-to-dry transition (Stevens et al. 2001, 2006) (Figs. 3a,b). A 600-yr period of high $\delta^{18} \mathrm{O}$ values occurs at about $5.5 \mathrm{kyr}$ BP over the Mirabad and Zeribar, suggesting a regional drought event (Stevens et al. 2006). Similarly, the record in Neor Lake also suggested a drying trend during the MH (Fig. 3c; Sharifi et al. 2015). In the western ME, the $\Delta P_{6.5-5 \mathrm{kyr}}$ is increased across the stalagmites from Jeita Cave in Lebanon (Fig. 3d; Verheyden et al. 2008), sediment records from the northern Red Sea (Figs. 3g,h; Arz et al. 2003), and sediment cores from the southeast Levantine Sea (Fig. 3i; Hamann et al. 2008), while it is nearly unchanged in speleothems from Soreq Cave (Fig. 3e; Zanchetta et al. 2014) and even decreased in sediment from the Dead Sea (Fig. 3j; Migowski et al. 2006; Litt et al. 2012). Roberts et al. (2011a) also show a decreasing trend after $6 \mathrm{kyr}$ BP over the eastern Mediterranean by combining isotopic data from lake sediments. The records over the Nefud agree with the increased precipitation anomalies while the $\delta^{18} \mathrm{O}$ (Whitney et al. 1983) and $\delta^{13} \mathrm{C}$ speleothems over the Star Cave and Surprise Cave indicate no precipitation change (Fleitmann et al. 2004). Additionally, eight records suggest an arid episode between 5.3 and 5.1 kyr BP over the ME. Some other proxy data also indicate an increase in $\Delta P_{6.5-5 \mathrm{kyr}}$ over the peripheral regions near the ME, such as reconstructions over the Caspian Sea (Overeem et al. 2003), the southeastern Arabian Peninsula (McClure 1976; Fleitmann and Matter 2009), and centralwestern Turkey (Roberts et al. 2001; Eastwood et al. 2007).

Although there are some uncertainties in the reconstructions, the reconstructed results are in good agreement with our simulated results from $\mathrm{MH}_{\mathrm{GREEN}}$ minus $\mathrm{MH}_{\text {DESERT }}$ experiments, which suggests that our model could capture the spatial change of $\Delta P_{6.5-5 \mathrm{kyr}}$. Meanwhile, the simulated increased precipitation is also consistent with climate change recorded in the proxy data over the Caspian Sea, southeastern Arabian Peninsula, and central-western Turkey, which further demonstrates the reliability of the modeling results.

The impact of the Saharan vegetation on the annual cycle of climatological precipitation is examined in Fig. 4. In the preindustrial (PI) experiment, almost no precipitation occurs over the northern Saharan desert region. Precipitation mainly occurs in winter over the Mediterranean region and concentrates in winter and early spring over the ME. These three regions represent three different rainfall regimes. Compared with the climatological precipitation in the PI experiment, the $\mathrm{MH}$ orbital forcing under the deserted Sahara condition 


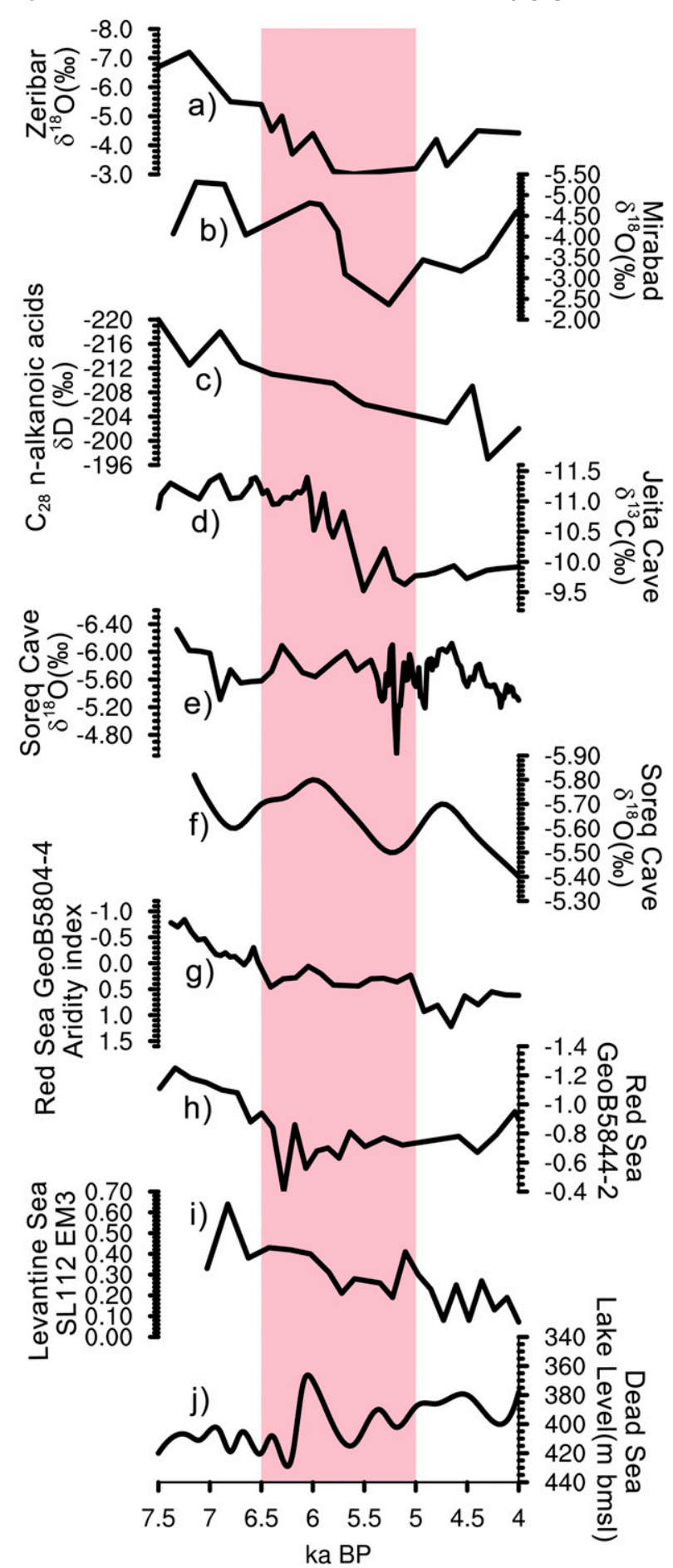

FIG. 3. The records over the ME region: (a) Zeribar $\delta^{18} \mathrm{O}$ (Stevens et al. 2006), (b) Lake Mirabad $\delta^{18} \mathrm{O}$ (Stevens et al. 2006), (c) Neor Lake compound-specific $\delta D$ (Sharifi et al. 2015), (d) Jeita Cave $\delta^{18} \mathrm{C}$ (Verheyden et al. 2008), (e),(f), Soreq Cave $\delta^{18} \mathrm{O}$ (Zanchetta et al. 2014; Bar-Matthews et al. 2000), (g),(h) aridity index from GeoB5804-4 and $\delta^{18} \mathrm{O}$ from GeoB5844-2 over the Red Sea (Arz et al. 2003), (i) sediment from SL112 over the Levantine Sea (Hamann et al. 2008), and (j) sediments over the Dead Sea (Litt et al. 2012). The red shading indicates the period of 6.5$5.0 \mathrm{kyr}$ BP.

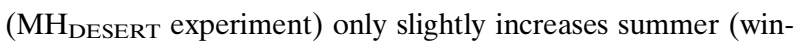
ter) precipitation over the northern Sahara (Mediterranean) but suppresses the winter precipitation over the ME. When we include the effect of Saharan vegetation $\left(\mathrm{MH}_{\mathrm{GREEN}}\right.$ experiment), the late summer (July-September) precipitation over the northern Sahara is greatly enhanced by the intensified North African summer monsoon (Fig. 4a) but it only has a weak impact on the summer precipitation over the Mediterranean and ME. Notably, the February-April mean ME precipitation increases from about $0.75 \mathrm{~mm}^{-1 a y}{ }^{-1}$ in the $\mathrm{MH}_{\text {DESERT }}$ experiment to about $1.14 \mathrm{~mm}_{\text {day }}{ }^{-1}$ in the $\mathrm{MH}_{\text {GREEN }}$ experiment (Fig. 4c), which means that the Saharan vegetation can substantially increase the February-April mean precipitation over the ME by about $52 \%$, compared to the Saharan desert condition. Besides, in the $\mathrm{MH}_{\mathrm{GREEN}}$ experiment, nearly no enhanced precipitation occurs during February-April over the northern Sahara (Fig. 4a), which means that the increased late winter and early spring precipitation over the ME occurs before the North African summer monsoon onset (9 May; Pausata et al. 2016).

\section{b. Causes of the increased precipitation over the $M E$}

Climatologically speaking, during February to April (FMA), a subtropical high pressure system controls the latitude belt between $10^{\circ}$ and $30^{\circ} \mathrm{N}$ over North Africa and the region bounded by $40^{\circ}-65^{\circ} \mathrm{E}$ (Fig. 5a). The moist westerly winds blow from the Atlantic to the ME and the accompanying ascending motion over Mesopotamia and the Zagros Mountains brings in the local rainy season (Fig. 5b).

Changing the Saharan land cover from desert to shrub leads to a decrease in surface albedo over northern Africa, allowing the surface to receive more incoming solar radiation in FMA (Fig. 6a). Thus, the 2-m air temperature is increased by about $3^{\circ}-5^{\circ} \mathrm{C}$ over the Saharan region (Fig. $6 \mathrm{~b}$ ), leading to a large land-ocean thermal contrast, which forms an anomalous low SLP anomaly over northern Africa. The integrated water vapor transport shows that the moisture flows eastward from the Atlantic Ocean to equatorial North Africa (Fig. 6c) through the low-level anomalous westerlies (Fig. 6e), which enhances the precipitation over tropical North Africa $\left(0^{\circ}-15^{\circ} \mathrm{N}\right)$. It also enhanced evaporation over tropical North Africa, accompanied by a strong release of surface latent heat flux (figure not shown), contributing to the surface cooling over $5^{\circ}-12^{\circ} \mathrm{N}$ (Fig. 6b), which induces the anomalous north-south temperature gradient over eastern North Africa. Then the low-level southwesterly anomalies are formed, transporting the moisture from eastern tropical Africa and the Red Sea into the ME region (Fig. 6c). Meanwhile, the water vapor is also transported from the Mediterranean region into the ME region through the mid- to upper-level westerly anomalies induced by the enhanced North African geopotential height (Fig. 6f). The enhanced moisture carried by westerly and southwesterly flow is lifted upon reaching the Zagros Mountains, causing an anomalous ascending motion there (Fig. 6d), substantially increasing the precipitation (Fig. 6c). The enhanced late winter and early spring precipitation anomaly center is located over the Tigris-Euphrates delta and the Zagros Mountains. 
(a) Northern Sahara

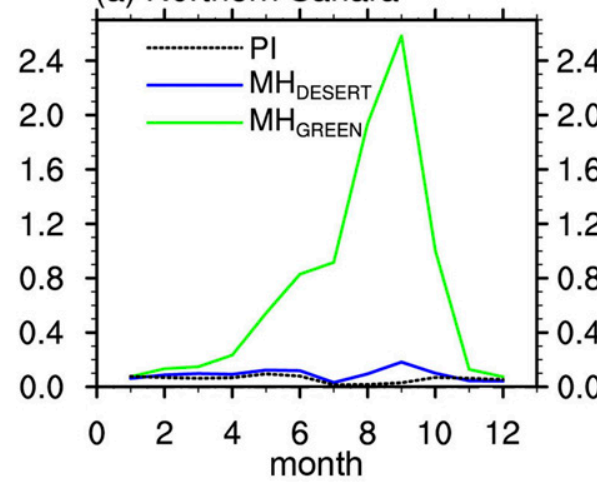

(b) Mediterranean

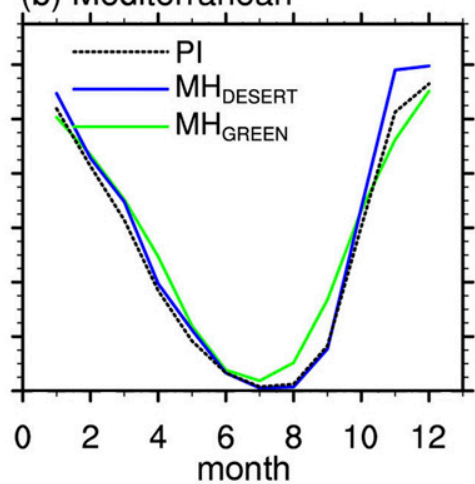

(c) Middle East

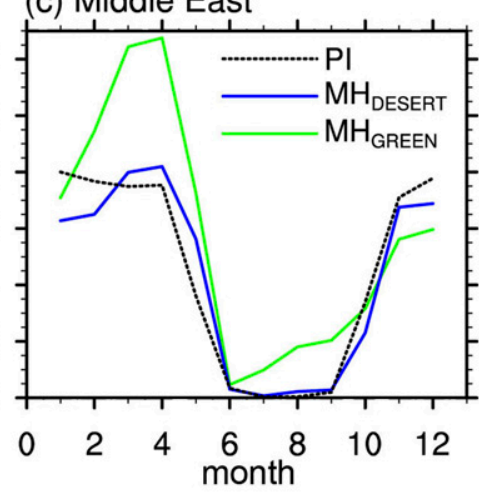

FIG. 4. The annual cycle of climatological precipitation $\left(\mathrm{mm} \mathrm{day}^{-1}\right)$ over (a) the northern Sahara, (b) the Mediterranean, and (c) the Middle East. Black dashed lines represent the results in the PI experiment, and blue and green lines denote the results from the $\mathrm{MH}_{\text {DESERT }}$ and $\mathrm{MH}_{\text {GREEN }}$ experiments, respectively.

The change in sea surface temperature (SST) also amplifies the atmospheric circulation and moisture change over the North Africa-Middle East regions. With the greening Sahara, the land-sea thermal contrast generates westerly anomalies along the western African coast, which suppress the coastal upwelling, increasing the SST there (Figs. 6b,e). Then the anomalous east-west SST gradient develops and strengthens the anomalous westerlies south of $10^{\circ} \mathrm{N}$, which further enhances the North African low-level cyclonic anomalies and brings more moisture to tropical North Africa.

To investigate whether the late winter and early spring precipitation response is mainly caused by the vegetated Sahara, the effect of orbital forcing $\left(\mathrm{MH}_{\text {DESERT }}\right.$ minus PI experiments) is detected and an additional $\mathrm{PI}_{\text {GREEN }}$ experiment is conducted (Table 1). The orbital forcing induces an anomalous cooling over North Africa and an anomalous warming over the Mediterranean and European region (Fig. 7a), which leads to the anomalous descending motion over equatorial Africa and eastern North Africa (Fig. 7e). However, no significant increase in precipitation is found in the ME under the orbital forcing (Fig. 7c). Meanwhile, the results (PI GREEN minus PI) show very similar changes in the precipitation, temperature, and atmospheric circulation (Figs. 7b,d,f) to those seen in the $\mathrm{MH}_{\mathrm{GREEN}}$ minus $\mathrm{MH}_{\mathrm{DESERT}}$ experiments (Fig. 6), which confirms that the Saharan vegetation itself plays the dominant role in increasing the ME late winter and early spring precipitation under the $\mathrm{MH}$ condition, rather than the combined effect of insolation and vegetation forcings.

\section{c. The potential impact on agriculture}

Previous studies found that the crop yield is sensitive to the change in solar radiation and temperature (i.e., Zhan et al. 2019). However, the input data of APSIM shows that the differences in daily surface downward solar radiation and daily temperature between the $\mathrm{MH}_{\text {DESERT }}$ and $\mathrm{MH}_{\text {GREEN }}$ experiments are small during February-April over Mesopotamia, but the daily precipitation is significantly enhanced under the effect of vegetated Sahara. Thus, using a crop model can be useful to explore whether the ME precipitation change suggested by the reconstructed data can induce a change in wheat yield during the MH (Araus et al. 2007; Riehl et al. 2014). (a) FMA Clim. Pr \& 850hPa winds

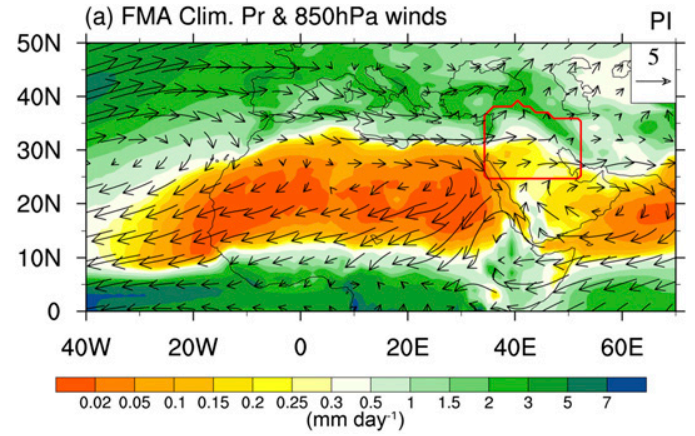

(b) FMA Clim. 500hPa OMEGA

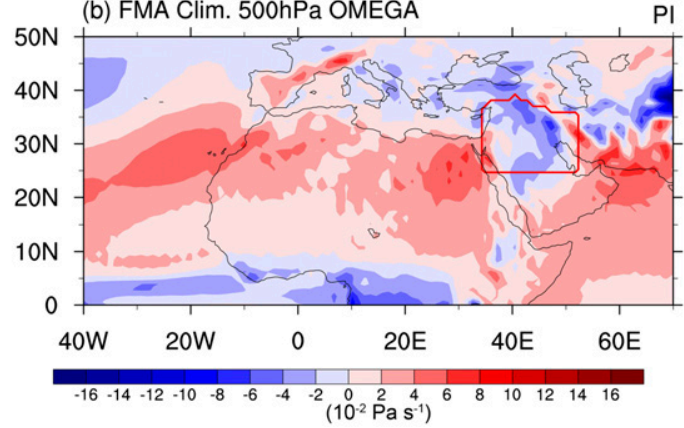

FIG. 5. February-April mean climatological (a) precipitation (color shading; $\mathrm{mm} \mathrm{day}^{-1}$ ) and winds at $850 \mathrm{hPa}$ (vectors; $\left.\mathrm{m} \mathrm{s}^{-1}\right)$ and (b) vertical velocity at $500 \mathrm{hPa}\left(10^{-2} \mathrm{~Pa} \mathrm{~s}^{-1}\right.$; negative values denote the ascending motions, and positive values denote the descending motions) in the PI experiment. The red-outlined box represents the ME region. 
(a) SSR

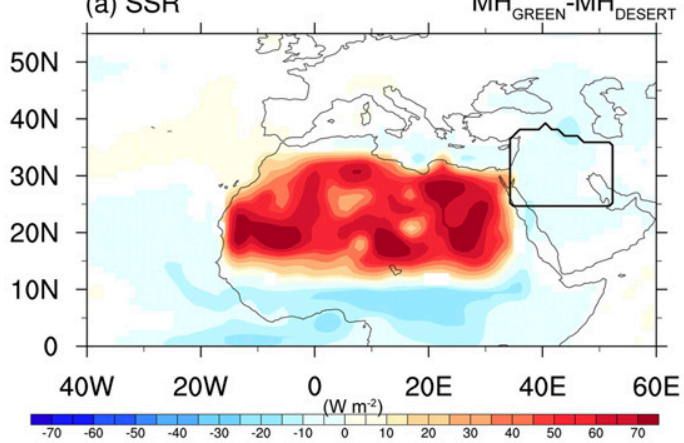

(c) $\operatorname{Pr} \&$ WVT

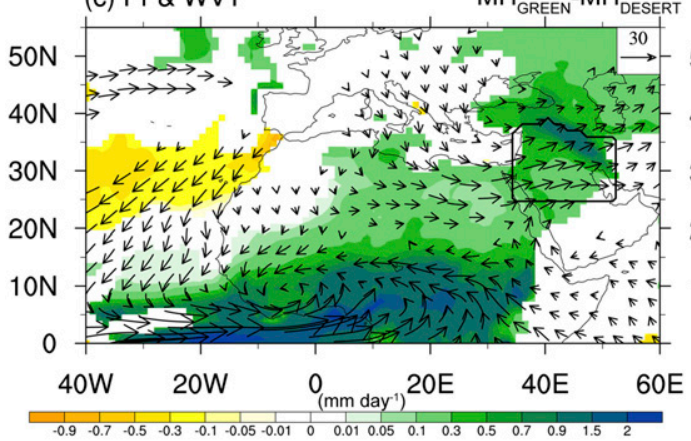

(e) 1000-850hPa GH \& UV

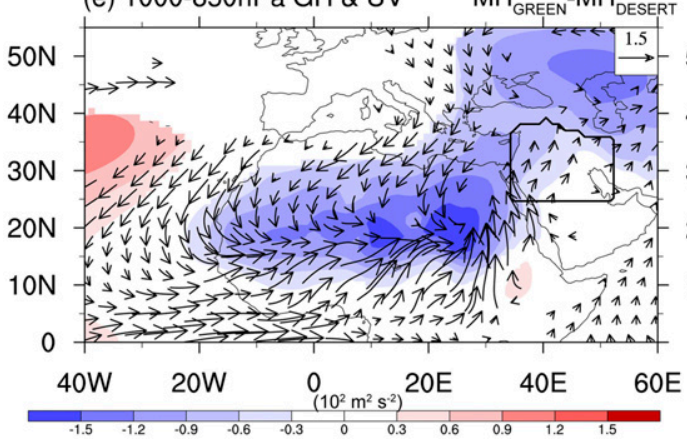

(b) TS, SST \& SLP

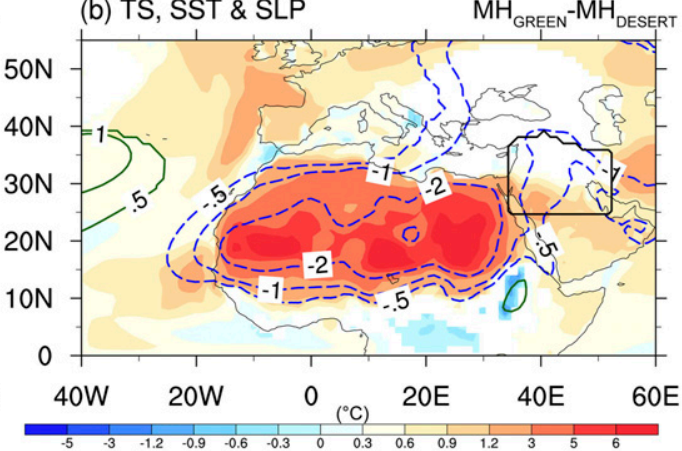

(d) $500 \mathrm{hPa}$ OMEGA

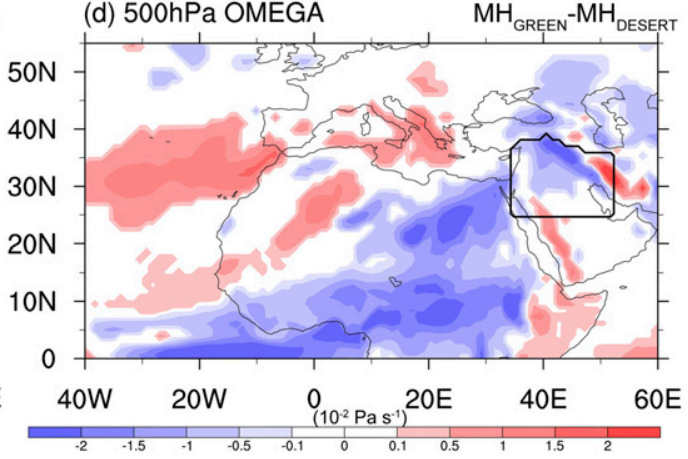

(f) 500-300hPa GH \& UV

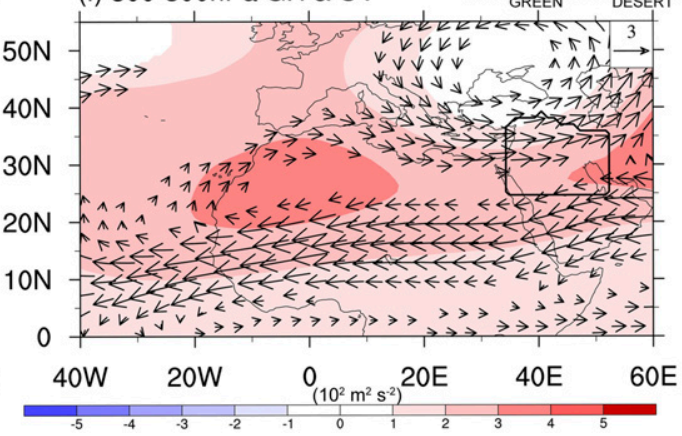

FIG. 6. Modeled February-April mean anomalies for $\mathrm{MH}_{\text {GREEN }}$ minus $\mathrm{MH}_{\text {DESERT }}$ experiments: (a) Anomalous surface net shortwave radiation $\left(\mathrm{W} \mathrm{m}^{-2}\right)$. (b) Anomalous air temperature at $2 \mathrm{~m}$ (color shading over the land; ${ }^{\circ} \mathrm{C}$ ), sea surface temperature (color shading over the ocean; ${ }^{\circ} \mathrm{C}$ ), and sea level pressure (contours; hPa). (c) Anomalous precipitation (color shading; $\mathrm{mm} \mathrm{day}^{-1}$ ) and vertically integrated water vapor transport (vectors; $\mathrm{kg} \mathrm{m}^{-1} \mathrm{~s}^{-1}$ ). (d) Anomalous vertical velocity at $500 \mathrm{hPa}\left(10^{-2} \mathrm{~Pa} \mathrm{~s}^{-1}\right)$. (e) Anomalous $1000-850-\mathrm{hPa}$ mean geopotential heights (color shading; $10^{2} \mathrm{~m}^{2} \mathrm{~s}^{-2}$ ) and winds (vectors; $\mathrm{m} \mathrm{s}^{-1}$ ). (f) Anomalous 500-300-hPa mean geopotential heights (color shading; $10^{2} \mathrm{~m}^{2} \mathrm{~s}^{-2}$ ) and winds (vectors; $\mathrm{m} \mathrm{s}^{-1}$ ) The black-outlined box represents the ME region. Only the significant anomalies of each variable with confidence level exceeding the $95 \%$ (via a two-tailed Student's $t$ test) are shaded and shown.

The averaged rain-fed production of wheat is about 500 $1400 \mathrm{~kg} \mathrm{ha}^{-1}$ over Mesopotamia (Buringh 1960; World Bank 2001), which is slightly higher than that in our idealized experiments under the PI condition (not shown). Under the $\mathrm{MH}$ deserted Sahara condition, the mean yields of wheat are roughly 717,656 , and $581 \mathrm{~kg} \mathrm{ha}^{-1}$ based on the brown clay, silty loam, and cracking clay, respectively (Fig. 8), similar to the PI condition. This means that the effect of orbital forcing does not significantly influence the wheat yield over the ME, probably because of the unchanged February-April mean precipitation and temperature (Fig. 7, left). When the Saharan vegetation is further included, the mean wheat yields are about 1539, 1435, and $1298 \mathrm{~kg} \mathrm{ha}^{-1}$ based on the brown clay, silty loam, and cracking clay, respectively, more than twice that under the deserted Sahara condition (Fig. 8). This is due to the Saharan greening that contributes to the westerly and southwesterly water vapor transport over the ME during the late winter and early spring, substantially enhancing the precipitation there (Fig. 6c), which leads to the increased wheat yields.

The simulated change in wheat yields agrees with the agricultural production changes from the reconstructions (Araus et al. 2007; Roberts et al. 2011b; Riehl et al. 2014). Riehl et al. 
(a) TS, SST \& SLP

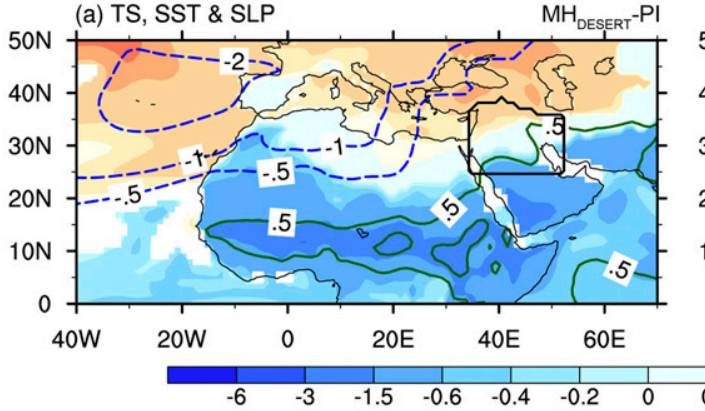

(c) $\mathrm{Pr}$

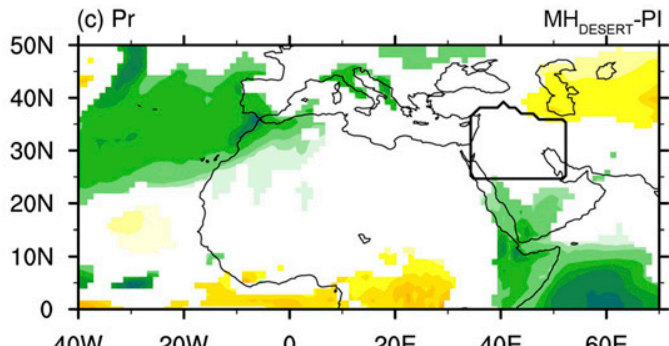

$40 \mathrm{~W}$ (b) TS, SST \& SLP

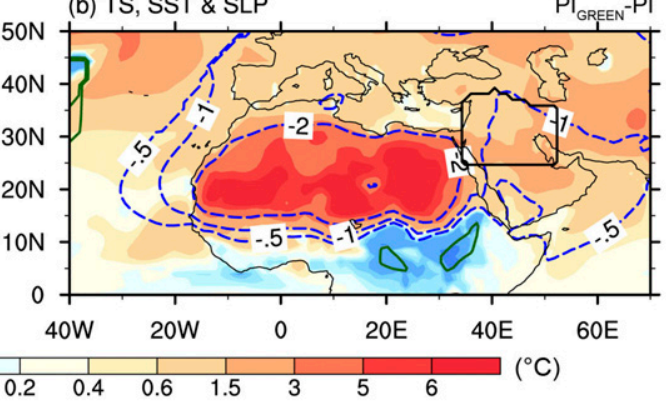

(d) $\mathrm{Pr}$

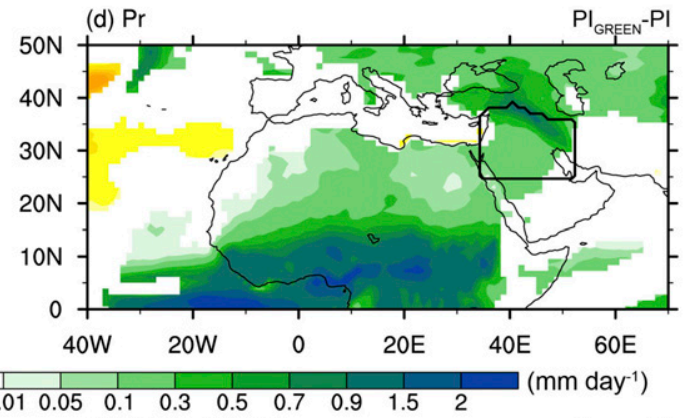

(e) 500hPa OMEGA
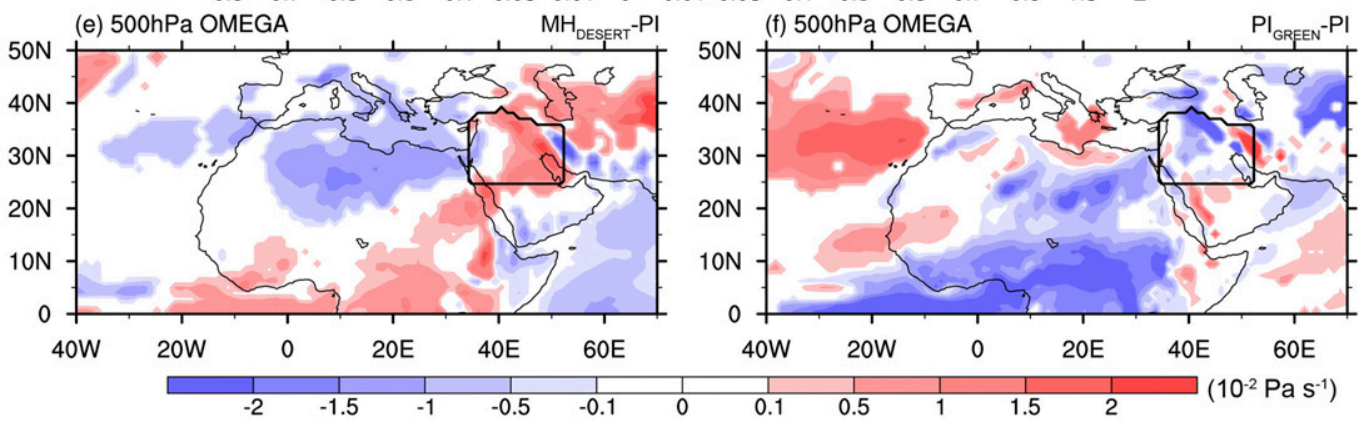

FIG. 7. Simulated February-April mean anomalies for (left) $M H_{\text {DESERT }}$ minus PI experiments and (right) $\mathrm{PI}_{\text {GREEN }}$ minus PI experiments for (a),(b) air temperature at $2 \mathrm{~m}$ over the land (color shading; ${ }^{\circ} \mathrm{C}$ ), sea surface temperature (color shading; ${ }^{\circ} \mathrm{C}$ ), and sea level pressure (contours; $\mathrm{hPa}$ ); (c),(d) precipitation (color shading; $\mathrm{mm}$ day $\left.^{-1}\right)$; and (e),(f), vertical velocity at $500 \mathrm{hPa}\left(10^{-2} \mathrm{~Pa} \mathrm{~s}^{-1}\right)$. The black-outlined box represents the ME region. Only the significant anomalies of each variable with confidence level exceeding the $95 \%$ (via a two-tailed Student's $t$ test) are shaded.

(2014) found that a high $\delta^{13} \mathrm{C}$ value occurred during $12-6 \mathrm{kyr}$ BP over the Near East, indicating good water supply for crop growth, which agrees with Araus et al. (2007). The higher agricultural production might have had a potential effect on the development of Ubaid period villages, Uruk period cities, and Sumerian civilization (Staubwasser and Weiss 2006; Roberts et al. 2011a,b). Existing reconstructions showed that the desertification of Saharan vegetation occurred at about $5.5 \mathrm{kyr}$ BP (McGee et al. 2013; Armitage et al. 2015; Shanahan et al. 2015; Collins et al. 2017). Studies also found that the drier climate occurred during 5.3-5.0 kyr BP in the interior areas of the Fertile Crescent and the spring crop-growing period decreased (Deckers et al. 2007; Riehl et al. 2008; Roberts et al. 2011b). Riehl et al. (2014) suggested that $\delta^{13} \mathrm{C}$ reached a minimum at about $5.2 \mathrm{kyr} \mathrm{BP}$, which was mainly caused by the decline over the inland regions of the Near East. From this study, the desertification of Sahara may decrease the late winter and early spring ME precipitation (Fig. 5c), resulting in the decline of cereal agriculture (Fig. 8), which is also recorded by reconstructions (Weiss 1986; Riehl et al. 2014).

\section{Discussion}

Under the effect of Saharan vegetation, Brayshaw et al. (2011) also found no change in ME precipitation during JuneSeptember, which is similar to this study. We further show that the Saharan vegetation can increase the late winter and early spring precipitation compared with that under the desert Sahara during the mid-Holocene. The $\delta^{18} \mathrm{O}$ records over Lake Zeribar and Lake Mirabad suggest that the severe drought during 5600-5000 yr BP results from the reduced spring precipitation (Stevens et al. 2001, 2006). However, most proxies could not prove that the wet-to-dry transition during the $\mathrm{MH}$ arises from the winter/early spring precipitation change (e.g., 
(a) Brown Clay

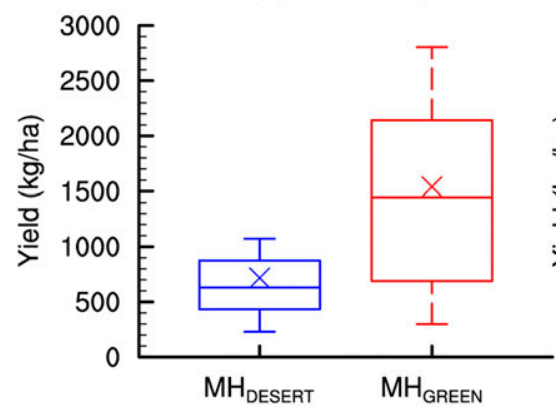

(b) Silty loam

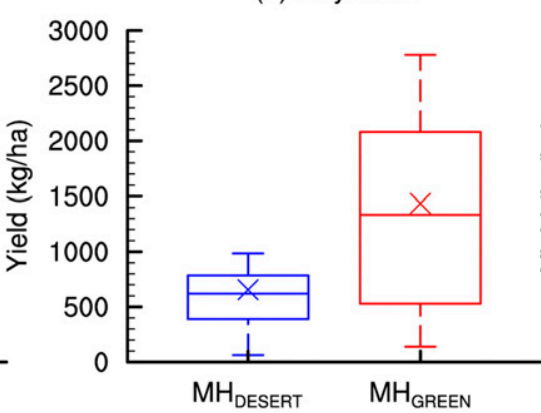

(c) Cracking Clay

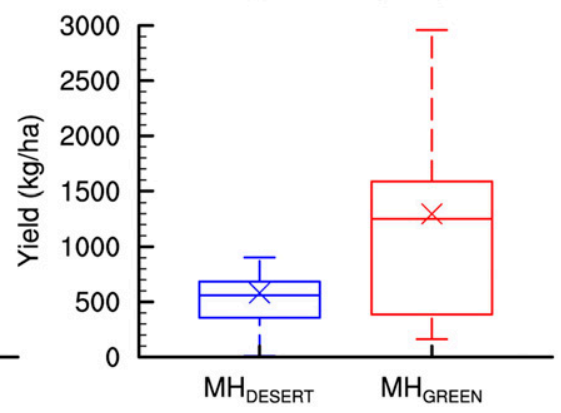

FIG. 8. Yield of wheat crops over Mesopotamia (north of $29^{\circ} \mathrm{N}$ over the ME) simulated by the crop model ASPIM, which is driven by the last 20 years of results from the $\mathrm{MH}_{\mathrm{DESERT}}$ (blue) and $\mathrm{MH}_{\mathrm{GREEN}}$ (red) experiments, for (a) brown clay, (b) silty loam, and (c) cracking clay soil types. The box-and-whisker plots show the 10th, 25th, 50th, 75th, and 90th intervals, and the crosses denote the mean.

Arz et al. 2003), which is hard to discuss the seasonal changes in the ME precipitation. Our study does not consider the vegetation change over the Arabian Peninsula (Hoelzmann et al. 1998), which might influence the local climate change (Claussen et al. 2013; Kaniewski et al. 2008). Meanwhile, the simulated ME precipitation change is small (Fig. 4c), especially when accounting for uncertainties. The percentage change in ME precipitation is large because the climatological precipitation in the $\mathrm{MH}_{\text {DESERT }}$ experiment is very small. Our experiments provide the potential possibilities of the green Sahara's impacts on ME during the mid-Holocene.

The relationship between the green Sahara and wet ME is still uncertain during the Holocene. Some reconstructions over the ME show a wetter condition in the early Holocene than the late Holocene, such as the $\delta^{18} O$ data over the Red Sea, Hoti Cave, Qunf Cave, Lake Zeribar, Soreq Cave, and Jeita Cave (Arz et al. 2003; Palchan and Torfstein 2019; Fleitmann and Matter 2009; Stevens et al. 2001; Zanchetta et al. 2014; Verheyden et al. 2008; Robert et al. 2011b; Fig. 9 in Clarke et al. 2016); some proxies show no trend or an increasing trend during the Holocene, such as records over the Dead Sea, $\delta^{13} C$ over the Soreq Cave, Sr/Ca ratios over Lake Mirabad (Migowski et al. 2006; Litt et al. 2012; Bar-Matthews and Ayalon 2011; Stevens et al. 2006). High-resolution climate proxies are very rare over the ME, which makes it difficult to comprehensively understand the characteristics and mechanism of the ME climate changes during the Holocene. Our idealized experiments tend to investigate the impacts of the end of the green Sahara on ME climate transition during the $\mathrm{MH}$, but it could not demonstrate the long-term relationship between the green Sahara and the ME precipitation during the Holocene. Meanwhile, it should be noted that dates of 6.5 and 5.0 kyr BP could not represent the difference between a fully vegetated and fully deserted Sahara. Some studies suggested that the northern Sahara Desert occurred about $5.5 \mathrm{kyr}$ BP but the southern Sahara/Sahel underwent desertification later (Shanahan et al. 2015; Dallmeyer et al. 2020), and the Sahara was likely still green in its central and southern locations in $5.0 \mathrm{kyr}$. This means that the difference between $\mathrm{MH}_{\text {GREEN }}$ and $\mathrm{MH}_{\text {DESERT }}$ can be an overestimate of climate change due to Saharan vegetation collapse during the $\mathrm{MH}$.
There are some caveats in the crop model experiments. First, the crop model is only used to test the sensitivities of crop production to climate change under the desert and green Sahara conditions. It is hard to determine the value of wheat yields in the mid-Holocene. Second, these idealized experiments deal with the rain-fed wheat production without considering irrigation, which may, to some extent, overestimate the differences in the climate impacts between $\mathrm{MH}_{\text {DESERT }}$ and $\mathrm{MH}_{\mathrm{GREEN}}$. Irrigation systems are critical to the development of civilizations (Wilkinson et al. 2015) but the historical practice of irrigation remains uncertain for most archaeological sites in the inland regions of the ME during the MH. Irrigation was found to develop over the eastern Mediterranean region (Roberts et al. 2011b), but it was suggested to reduce over the southern Mesopotamia because the agricultural technology was not enough to cope with severe drought around 5.2 kyr BP (Nutzel 2004). At the same time, proxy data also implied a general reduction in crop yields over the Euphrates region (Riehl et al. 2014). Third, emmer wheat was widely planted over the Near East during the Holocene because it has more favorable harvesting properties (Araus et al. 2007; Salamini et al. 2002). Since there is no ancient emmer in the APSIM, we chose modern wheat as a substitute without considering the changes in the diurnal cycle, crop types, and planting technology during the Holocene.

The simulated decrease in wheat yields during the desertification of Sahara agrees with the reconstructions (Weiss 1986; Riehl et al. 2014), which might have a potential influence on the abrupt collapse of late Uruk society across the middle Euphrates region (Staubwasser and Weiss 2006). Meanwhile, Clarke et al. (2016) also inferred that the Uruk expansion and establishment of intrusive migrant towns occurred during a period of climatic deterioration characterized by severe and protracted aridity from 5.7 to $5.1 \mathrm{kyr} \mathrm{BP}$, and the final Uruk contraction coincided with the inferred rainfall minima around 5.2-5.1 kyr BP. However, the coast was located more inland during the $\mathrm{MH}$ compared to the current coast (Kennett and Kennett 2006), and the influence of drought events on agriculture was small in the coastal areas (Riehl et al. 2014). Meanwhile, it should be noted that the climate is only one of the factors driving societal dynamics and it is difficult to 
separate from other internal societal factors or demonstrate to what extent it might induce social changes. More societal and cultural evidence is needed in future research.

\section{Conclusions}

Some proxy records suggest that the Middle East more likely experienced a change from wetter to much drier conditions during the period $6500-5000 \mathrm{yr}$ BP. Using the results from ECEarth, we found that the orbit-induced Saharan vegetation collapse could produce this climate transition from humid to more arid conditions over the $\mathrm{ME}$ at the end of the midHolocene. Some previous studies suggested that the ME precipitation can be affected by the Afro-Asian monsoon during the mid-Holocene (i.e., Wanner et al. 2008), but we found that neither the change in the North African summer monsoon (Tierney et al. 2017) nor that in the Asian summer monsoon (Sun et al. 2019) can reach the ME. Our modeling work provides a new understanding of the mid-Holocene ME moisture transition by including the green Sahara, which substantially increases the late winter and early spring precipitation over the Mesopotamia and Zagros Mountains. This mechanism would help to explain the rapid sign of climate change at the end of the mid-Holocene. Since the late winter and early spring precipitation is crucial to agricultural productivity in the ME, the crop model experiments suggest a higher wheat yield in Mesopotamia caused by the increased precipitation under the vegetated Sahara, compared with the deserted Sahara. Our study provides a new understanding of the climate shift over the ME associated with the mid-Holocene and suggests that that the simulation of the Saharan land cover (i.e., grassland and shrubland) is of great importance in modeling future ME climate change.

Acknowledgments. We thank paleoclimate researchers who provided the proxy records (listed in Table 2) and GPCP and NCEP2 for providing the dataset. We are grateful to three anonymous reviewers and the editor for their valuable comments and suggestions. This research is jointly supported by the National Key Research and Development Program of China (2016YFA0600401), National Natural Science Foundation of China (41971108, 41420104002, 41671197, and 41971021), Program of Innovative Research Team of Jiangsu Higher Education Institutions of China, and Priority Academic Program Development of Jiangsu Higher Education Institutions (164320H116). Qiong Zhang acknowledges support from the Swedish Research Council VR project 2017-04232 "Simulating the Green Sahara with an Earth System Model". The simulations were performed on resources provided by the Swedish National Infrastructure for Computing (SNIC) at NSC and Cray XC30 HPC systems at ECMWF. This is Publication Number 11167 of SOEST, Publication Number 1480 of the IPRC, and Publication Number 328 of the Earth System Modeling Center.

Data availability statement. The simulation results are available upon request from author Jian Liu. Paleoclimate researchers provided the proxy records (listed in Table 2) and GPCP and NCEP2 provided the dataset.

\section{REFERENCES}

Adler, R. F., and Coauthors, 2003: The version 2 Global Precipitation Climatology Project (GPCP) monthly precipitation analysis (1979-present). J. Hydrometeor., 4, 1147-1167, https://doi.org/ 10.1175/1525-7541(2003)004<1147:TVGPCP >2.0.CO;2.

Araus, J. L., J. P. Ferrio, R. Buxo, and J. Voltas, 2007: The historical perspective of dryland agriculture: Lessons learned from 10000 years of wheat cultivation. J. Exp. Bot., 58, 131145, https://doi.org/10.1093/jxb/erl133.

Armitage, S. J., C. S. Bristow, and N. A. Drake, 2015: West African monsoon dynamics inferred from abrupt fluctuations of Lake Mega-Chad. Proc. Natl. Acad. Sci. USA, 112, 8543-8548, https://doi.org/10.1073/pnas.1417655112.

Arz, H. W., F. Lamy, J. Pätzold, P. J. Muller, and M. Prins, 2003: Mediterranean moisture source for an early-Holocene humid period in the northern Red Sea. Science, 300, 118-121, https:// doi.org/10.1126/science.1080325.

Barcikowska, M. J., S. B. Kapnick, and F. Feser, 2018: Impact of largescale circulation changes in the North Atlantic sector on the current and future Mediterranean winter hydroclimate. Climate Dyn., 50, 2039-2059, https://doi.org/10.1007/s00382-017-3735-5.

Bar-Matthews, M., and A. Ayalon, 2011: Mid-Holocene climate variations revealed by high-resolution speleothem records from Soreq Cave, Israel and their correlation with cultural changes. Holocene, 21, 163-171, https://doi.org/10.1177/ 0959683610384165.

,-- , and A. Kaufman, 2000: Timing and hydrological conditions of Sapropel events in the eastern Mediterranean, as evident from speleothems, Soreq cave, Israel. Chem. Geol., 169, 145-156, https://doi.org/10.1016/S0009-2541(99)00232-6.

Braconnot, P., and Coauthors, 2012: Evaluation of climate models using palaeoclimatic data. Nat. Climate Change, 2, 417-424, https://doi.org/10.1038/nclimate1456.

Brayshaw, D. J., C. M. C. Rambeau, and S. J. Smith, 2011: Changes in Mediterranean climate during the Holocene: Insights from global and regional climate modelling. Holocene, 21, 15-31, https://doi.org/10.1177/0959683610377528.

Buringh, P., 1960: Soils and Soil Conditions in Iraq. Ministry of Agriculture, $322 \mathrm{pp}$.

Clarke, J., and Coauthors, 2016: Climatic changes and social transformations in the Near East and North Africa during the 'long' 4th millennium BC: A comparative study of environmental and archaeological evidence. Quat. Sci. Rev., 136, 96121, https://doi.org/10.1016/j.quascirev.2015.10.003.

Claussen, M., and V. Gayler, 1997: The greening of the Sahara during the mid-Holocene: Results of an interactive atmosphere-biome model. Global Ecol. Biogeogr. Lett., 6, 369-377, https://doi.org/ $10.2307 / 2997337$.

— - S. Bathiany, V. Brovkin, and T. Kleinen, 2013: Simulated climate-vegetation interaction in semi-arid regions affected by plant diversity. Nat. Geosci., 6, 954-958, https://doi.org/ 10.1038/ngeo1962.

Collins, J. A., and Coauthors, 2017: Rapid termination of the African Humid Period triggered by northern high-latitude cooling. Nat. Commun., 8, 1372, https://doi.org/10.1038/s41467-017-01454-y.

Dallmeyer, A., M. Claussen, S. J. Lorenz, and T. Shanahan, 2020: The end of the African humid period as seen by a transient comprehensive Earth system model simulation of the last 8000 years. Climate Past, 16, 117-140, https://doi.org/10.5194/cp-16-117-2020.

Davies, F. J., H. Renssen, M. Blaschek, and F. Muschitiello, 2015: The impact of Sahara desertification on Arctic cooling during the Holocene. Climate Past, 11, 571-586, https://doi.org/ 10.5194/cp-11-571-2015. 
Davis, B. A. S., and A. C. Stevenson, 2007: The 8.2 ka event and early-mid Holocene forest, fires, and flooding in the Central Ebro Desert, NE Spain. Quat. Sci. Rev., 26, 1695-1712, https:// doi.org/10.1016/j.quascirev.2007.04.007.

Deckers, K., L. Herveux, C., Kuzucuoğlu, J. McCorriston, H. Pessin, S. Riehl, and E. Vila, 2007: Characteristics and changes in archaeology-related environmental data during the third millennium BC in upper Mesopotamia. Collective comments to the data discussed during the symposium. Sociétés humaines et changement climatique à la fin du Troisième Millénaire: Une crise a-t-elle eu lieu en Haute Mésopotamie? C. Kuzucuoğlu and C.Marro, Eds., IFEA, 573-580.

deMenocal, P., and Coauthors, 2000: Abrupt onset and termination of the African humid period: Rapid climate responses to gradual insolation forcing. Quat. Sci. Rev., 19, 347-361, https:// doi.org/10.1016/S0277-3791(99)00081-5.

Eastwood, W. J., M. J. Leng, N. Roberts, and B. Davis, 2007: Holocene climate change in the eastern Mediterranean region: A comparison of stable isotope and pollen data from Lake Golhisar, southwest Turkey. J. Quat. Sci., 22, 327-341, https://doi.org/10.1002/jqs.1062.

Evans, J. P., 2009: 21st century climate change in the Middle East. Climatic Change, 92, 417-432, https://doi.org/10.1007/s10584008-9438-5.

Fleitmann, D., and A. Matter, 2009: The speleothem record of climate variability in southern Arabia. C. R. Geosci., 341, 633642, https://doi.org/10.1016/j.crte.2009.01.006.

,-- J. Pint, and M. A. Al-Shanti, 2004: The speleothem record of climate change in Saudi Arabia: Saudi Geological Survey. Jeddah: Saudi Geological Survey Open-File Report SGS-OF-2004-8, 40 pp., https://citeseerx.ist.psu.edu/viewdoc/ download?doi=10.1.1.527.5450\&rep $=$ rep1\&type $=$ pdf.

Hamann, Y., W. Ehrmann, G. Schmiedl, S. Krüger, J. B. Stuut, and T. Kuhnt, 2008: Sedimentation processes in the eastern Mediterranean Sea during the Late Glacial and Holocene revealed by end-member modelling of the terrigenous fraction in marine sediments. Mar. Geol., 248, 97-114, https://doi.org/ 10.1016/j.margeo.2007.10.009.

Harrison, S. P., and Coauthors, 2014: Climate model benchmarking with glacial and mid-Holocene climates. Climate Dyn., 43, 671-688, https://doi.org/10.1007/s00382-013-1922-6.

Hazeleger, W., and Coauthors, 2010: EC-Earth: A seamless Earthsystem prediction approach in action. Bull. Amer. Meteor. Soc., 91, 1357-1364, https://doi.org/10.1175/2010BAMS2877.1.

Hély, C., A. M. Lézine, and A. P. D. Contributors, 2014: Holocene changes in African vegetation: Tradeoff between climate and water availability. Climate Past, 10, 681-686, https://doi.org/ 10.5194/cp-10-681-2014.

Hersbach, H., and Coauthors, 2018: Operational global reanalysis: Progress, future directions and synergies with NWP. ECMWF ERA Rep Series N27, https://www.ecmwf.int/node/18765.

Hoelzmann, P., D. Jolly, S. Harrison, F. Laarif, R. Bonnefille, and H. Pachur, 1998: Mid-Holocene land-surface conditions in northern Africa and the Arabian Peninsula: A data set for the analysis of biogeophysical feedbacks in the climate system. Global Biogeochem. Cycles, 12, 35-51, https://doi.org/10.1029/97GB02733.

Holzworth, D. P., and Coauthors, 2014: APSIM-Evolution towards a new generation of agricultural systems simulation. Environ. Modell. Software, 62, 327-350, https://doi.org/ 10.1016/j.envsoft.2014.07.009.

Kanamitsu, M., and Coauthors, 2002: NCEP-DOE AMIP-II Reanalysis (R-2). Bull. Amer. Meteor. Soc., 100, 1631-1644, https://doi.org/10.1175/BAMS-83-11-1631.
Kaniewski, D., E. Paulissen, E. Van Campo, M. Al-Maqdissi, J. Bretschneider, and K. Van Lerberghe, 2008: Middle East coastal ecosystem response to middle-to-late Holocene abrupt climate changes. Proc. Natl. Acad. Sci. USA, 105, 1394113 946, https://doi.org/10.1073/pnas.0803533105.

Kennett, D., and J. Kennett, 2006: Early state formation in southern Mesopotamia: Sea levels, shorelines, and climate change. J. Island Coast. Archaeol., 1, 67-99, https://doi.org/ 10.1080/15564890600586283.

Kröpelin, S., and Coauthors, 2008: Climate-driven ecosystem succession in the Sahara: The past 6000 years. Science, 320, 765768, https://doi.org/10.1126/science.1154913.

Kutzbach, J. E., 1981: Monsoon climate of the early Holocene: Climate experiment with the Earth's orbital parameters for 9000 years ago. Science, 214, 59-61, https://doi.org/10.1126/science. 214.4516.59.

_ , and B. L. Otto-Bliesner, 1982: The sensitivity of the AfricanAsian monsoonal climate to orbital parameter changes for 9000 years B.P. in a low-resolution general circulation model. J. Atmos. Sci., 39, 1177-1188, https://doi.org/10.1175/15200469(1982)039<1177:TSOTAA > 2.0.CO;2.

— G. Gonan, J. Foley, and S. P. Harrison, 1996: Vegetation and soil feedbacks on the response of the African monsoon to orbital forcing in the early to middle Holocene. Nature, 384, 623-626, https://doi.org/10.1038/384623a0.

Litt, T., C. Ohlwein, F. Neumann, A. Hense, and M. Stein, 2012: Holocene climate variability in the Levant from the Dead Sea pollen record. Quat. Sci. Rev., 49, 95-105, https://doi.org/ 10.1016/j.quascirev.2012.06.012.

Madec, G., 2008: NEMO ocean engine. Note du Pôle de modélisation 27, Institut Pierre-Simon Laplace, 396 pp., https://www.nemoocean.eu/wp-content/uploads/NEMO_book.pdf.

Magny, M., and J. N. Haas, 2004: A major widespread climatic change around $5300 \mathrm{cal}$. yr BP at the time of the Alpine Iceman. J. Quat. Sci., 19, 423-430, https://doi.org/10.1002/jqs.850.

Mariotti, A., Y. T. Pan, N. Zeng, and A. Alessandri, 2015: Longterm climate change in the Mediterranean region in the midst of decadal variability. Climate Dyn., 44, 1437-1456, https:// doi.org/10.1007/s00382-015-2487-3.

Mauri, A., B. A. S. Davis, P. M. Collins, and J. O. Kaplan, 2014: The influence of atmospheric circulation on the mid-Holocene climate of Europe: A data-model comparison. Climate Past, 10, 1925-1938, https://doi.org/10.5194/cp-10-1925-2014.

McClure, H. A., 1976: Radiocarbon chronology of late Quaternary lakes in the Arabian Desert. Nature, 411, 290-293, https:// doi.org/10.1038/263755A0.

McGee, D., P. B. deMenocal, G. Winckler, J. B. W. Stuut, and L. I. Bradtmiller, 2013: The magnitude, timing and abruptness of changes in North African dust deposition over the last 20,000 yr. Earth Planet. Sci. Lett., 371-372, 163-176, https:// doi.org/10.1016/j.epsl.2013.03.054.

Migowski, C., M. Stein, S. Prasad, J. F. W. Negendank, and A. Agnon, 2006: Holocene climate variability and cultural evolution in the Near East from the Dead Sea sedimentary record. Quat. Res., 66, 421-431, https://doi.org/10.1016/j.yqres.2006.06.010.

Moeller, C., S. Asseng, J. Berger, and S. P. Milroy, 2009: Plant available soil water at sowing in Mediterranean environments-Is it a useful criterion to aid nitrogen fertiliser and sowing decisions? Field Crops Res., 114, 127-136, https://doi.org/10.1016/j.fcr.2009.07.012.

_ J. Sauerborn, P. D. Voil, A. M. Manschadi, M. Pala, and H. Meinke, 2014: Assessing the sustainability of wheat-based cropping systems using simulation modelling: Sustainability $=42$ ? Sustain. Sci., 9 (1), 1-16, https://doi.org/10.1007/s11625-013-0228-2. 
Muschitiello, F., Q. Zhang, H. S. Sundqvist, F. Davies, and H. Renssen, 2015: Arctic climate response to the termination of the African Humid Period. Quat. Sci. Rev., 125, 91-97, https://doi.org/10.1016/j.quascirev.2015.08.012.

Nissen, H. J., 1988: The Early History of the Ancient Near East. University of Chicago Press, $224 \mathrm{pp}$.

Nutzel, W., 2004: Einführung in die Geo-Archäologie des Vorderen Orients (Introduction to the Geoarcheology of the Middle East). Reichert, 122 pp.

Overeem, I., S. B. Kroonenberg, A. Veldkamp, K. Groenesteijn, G. V. Rusakov, and A. A. Svitoch, 2003: Small-scale stratigraphy in a large ramp delta: Recent and Holocene sedimentation in the Volga delta, Caspian Sea. Sediment. Geol., 159, 133-157, https://doi.org/10.1016/S0037-0738(02)00256-7.

Palchan, D., and A. Torfstein, 2019: A drop in Sahara dust fluxes records the northern limits of the African Humid Period. Nat. Commun., 10, 3803, https://doi.org/10.1038/s41467-019-11701-z.

Pausata, F. S. R., G. Messori, and Q. Zhang, 2016: Impacts of dust reduction on the northward expansion of the African monsoon during the Green Sahara period. Earth Planet. Sci. Lett. 434, 298-307, https://doi.org/10.1016/j.epsl.2015.11.049.

, and Coauthors, 2017a: Tropical cyclone activity enhanced by Sahara greening and reduced dust emissions during the African Humid Period. Proc. Natl. Acad. Sci. USA, 114, 62216226, https://doi.org/10.1073/pnas.1619111114.

_ ENSO activity during the mid-Holocene. Nat. Commun., 8, 16020, https://doi.org/10.1038/ncomms16020.

Rachmayani, R., M. Prange, and M. Schulz, 2016: Intra-interglacial climate variability: Model simulations of marine isotope stages 1, 5, 11, 13, and 15. Climate Past, 12, 677-695, https://doi.org/ 10.5194/cp-12-677-2016.

Riehl, S., R. A. Bryson, K. E. Pustovoytov, and R. A. Bryson, 2008: Changing growing conditions for crops during the Near Eastern Bronze Age (3000-1200 BC): The stable carbon isotope evidence. J. Archaeol. Sci., 35, 1011-1022, https://doi.org/ 10.1016/j.jas.2007.07.003.

—, K. E. Pustovoytov, H. Weippert, S. Klett, and F. Hole, 2014: Drought stress variability in ancient Near Eastern agricultural systems evidenced by $\delta^{13} \mathrm{C}$ in barley grain. Proc. Natl. Acad. Sci. USA, 111, 12348-12 353, https://doi.org/10.1073/pnas.1409516111.

Roberts, N., and Coauthors, 2001: The tempo of Holocene climatic change in the eastern Mediterranean region: New high-resolution crater-lake sediment data from central Turkey. Holocene, 11, 721-736, https://doi.org/10.1191/09596830195744.

— , D. Brayshaw, C. Kuzucuoğlu, R. Perez, and L. Sadori, 2011a: The mid-Holocene climatic transition in the Mediterranean: Causes and consequences. Holocene, 21, 3-13, https://doi.org/ 10.1177/0959683610388058.

—, W. J. Eastwood, C. Kuzucuoglu, G. Fiorentino, and V. Caracuta, 2011b: Climatic, vegetation and cultural change in the eastern Mediterranean during the mid-Holocene environmental transition. Holocene, 21, 147-162, https:// doi.org/10.1177/0959683610386819.

Salamini, F., H. Ozkan, A. Brandolini, R. Schafer-Pregl, and W. Martin, 2002: Genetics and geography of wild cereal domestication in the Near East. Nat. Rev. Genet., 3, 429-441, https://doi.org/10.1038/nrg817.

Shanahan, T. M., and Coauthors, 2015: The time-transgressive termination of the African humid period. Nat. Geosci., 8, 140144, https://doi.org/10.1038/ngeo2329.

Sharifi, A., and Coauthors, 2015: Abrupt climate variability since the last deglaciation based on a high-resolution, multi-proxy peat record from NW Iran: The hand that rocked the cradle of civilization. Quat. Sci. Rev., 123, 215-230, https://doi.org/ 10.1016/j.quascirev.2015.07.006.

- , and Coauthors, 2018: Early-Holocene greening of the AfroAsian dust belt changed sources of mineral dust in West Asia. Earth Planet. Sci. Lett., 481, 30-40, https://doi.org/10.1016/ j.epsl.2017.10.001.

Sirocko, F., M. Sarnthein, and H. Erienkeuser, 1993: Century-scale events in monsoonal climate over the past 24,000 years. Nature, 364, 322-324, https://doi.org/10.1038/364322a0.

Skinner, C. B., and C. J. Poulsen, 2016: The role of fall season tropical plumes in enhancing Saharan rainfall during the African Humid Period. Geophys. Res. Lett., 43, 349-358, https://doi.org/10.1002/2015GL066318.

Staubwasser, M., and H. Weiss, 2006: Holocene climate and cultural evolution in late prehistoric-early historic West Asia. Quat. Res., 66, 372-387, https://doi.org/10.1016/j.yqres.2006.09.001.

Stevens, L. R., H. E. Wright, and E. Ito, 2001: Proposed changes in seasonality of climate during the late-glacial and Holocene at Lake Zeribar, Iran. Holocene, 11, 747-755, https://doi.org/ 10.1191/09596830195762.

— - E. Ito, A. Schwalb, and H. E. Wright Jr., 2006: Timing of atmospheric precipitation in the Zagros Mountains inferred from a multi-proxy record from Lake Mirabad, Iran. Quat. Res., 66, 494-500, https://doi.org/10.1016/j.yqres.2006.06.008.

Sun, W. Y., and Coauthors, 2019: Northern Hemisphere land monsoon precipitation increased by the Green Sahara during middle Holocene. Geophys. Res. Lett., 46, 9870-9879, https:// doi.org/10.1029/2019GL082116.

Swann, A. L. S., I. Y. Fung, Y. Liu, and J. C. H. Chiang, 2014: Remote vegetation feedbacks and the mid-Holocene Green Sahara. J. Climate, 27, 4857-4870, https://doi.org/10.1175/JCLI-D-13-00690.1.

Taylor, K. E., R. J. Stouffer, and G. A. Meehl, 2012: An overview of CMIP5 and the experiment design. Bull. Amer. Meteor. Soc., 93, 485-498, https://doi.org/10.1175/BAMS-D-11-00094.1.

Tierney, J. E., F. S. R. Pausata, and P. B. deMenocal, 2017: Rainfall regimes of the Green Sahara. Sci. Adv., 3, e1601503, https:// doi.org/10.1126/sciadv.1601503.

Tuenter, E., S. L. Weber, F. J. Hilgen, and L. J. Lourens, 2007: Simulating sub-Milankovitch climate variations associated with vegetation dynamics. Climate Past, 3, 169-180, https:// doi.org/10.5194/cp-3-169-2007.

Uppala, S. M., and Coauthors, 2005: The ERA-40 Re-Analysis. Quart. J. Roy. Meteor. Soc., 131, 2961-3012, https://doi.org/ 10.1256/qj.04.176.

Valcke, S., 2006: OASIS3 user guide. Program for Integrated Earth System Modeling PRISM Tech. Rep. 3, 64 pp., https:// www.prism.enes.org/Publications/Reports/oasis3_UserGuide_ T3.pdf.

Vancoppenolle, M., T. Fichefet, H. Goosse, S. Bouillon, G. Madec, and M. A. M. Maqueda, 2009: Simulating the mass balance and salinity of Arctic and Antarctic sea ice. 1. Model description and validation. Ocean Modell., 27, 33-53, https:// doi.org/10.1016/j.ocemod.2008.10.005.

Verheyden, S., F. Nader, H. Cheng, L. Edwards, and R. Swennen, 2008: Paleoclimate reconstruction in the Levant region from the geochemistry of a Holocene stalagmite from the Jeita cave, Lebanon. Quat. Res., 70, 368-381, https://doi.org/ 10.1016/j.yqres.2008.05.004.

Waldmann, N., A. Torfstein, and M. Stein, 2010: Northward intrusions of low- and mid-latitude storms across the Saharo-Arabian belt during past interglacials. Geology, 38, 567-570, https:// doi.org/10.1130/G30654.1. 
Wanner, H., and Coauthors, 2008: Mid- to Late Holocene climate change: An overview. Quat. Sci. Rev., 27, 1791-1828, https:// doi.org/10.1016/j.quascirev.2008.06.013.

Watrin, J., A. Mercuri, C. Hély, and A. Ballouche, 2009: Plant migration and plant communities at the time of the "green Sahara." C. R. Geosci., 341, 656-670, https://doi.org/10.1016/ j.crte.2009.06.007.

Weiss, H., 1986: The origins of Tell Leilan and the conquest of space in third millennium Mesopotamia. The Origins of Cities in Dry Farming Syria and Mesopotamia in the Third Millenium B.C., H. Weiss Ed., Four Quarters Guilford, 71-108.

Whitney, J. W., D. J. Faulkender, and M. Rubin, 1983: The environmental history and present conditions of the northern sand seas of Saudi Arabia. United States Open File Report OF-03-95, 39 pp., https://doi.org/10.3133/ofr83749.

Wick, L., G. Lemcke, and M. Sturm, 2003: Evidence of late glacial and Holocene climatic change and human impact in eastern Anatolia: High-resolution pollen, charcoal, isotopic and geochemical records from the laminated sediments of Lake
Van, Turkey. Holocene, 13, 665-675, https://doi.org/10.1191/ 0959683603hl653rp.

Wilkinson, T. J., L. Rayne, and J. Jotheri, 2015: Hydraulic landscapes in Mesopotamia: The role of human niche construction. Water Hist., 7, 397-418, https://doi.org/10.1007/s12685-015-0127-9.

World Bank, 2001: Syrian Arab Republic irrigation sector report. World Bank Middle East and North Africa region Rural development, water, and environment group Rep. 22602-SYR, $95 \mathrm{pp}$.

Zanchetta, G., M. Bar-Matthews, R. N. Drysdale, P. Lionello, A. Ayalon, J. C. Hellstorm, I. Isola, and E. Regattieri, 2014: Coeval dry events in the central and eastern Mediterranean basin at 5.2 and 5.6 ka recorded in Corchia (Italy) and Soreq caves (Israel) speleothems. Global Planet. Change, 122, 130139, https://doi.org/10.1016/j.gloplacha.2014.07.013.

Zhan, P., W. Zhu, T. Zhang, X. Cui, and N. Li, 2019: Impacts of sulfate geoengineering on rice yield in China: Results from a multimodel ensemble. Earth's Future, 7, 395-410, https:// doi.org/10.1029/2018EF001094. 